\title{
Apnoea following suxamethonium: the genetic study of four generations of a family
}

\author{
ALAN A MORGAN \\ From General Practice, Ilford, Essex
}

SUMMARY Nineteen subjects were investigated as a result of apnoea following the administration of suxamethonium occurring in one member of the family. Examination of the blood for cholinesterase activity, dibucaine number, and fluoride number was carried out and the appropriate genotype determined. The significance of the genetic variation of plasma cholinesterase in relation to suxamethonium apnoea is discussed. Five subjects had the genotype $E_{1}^{u} E_{1}^{u}$, seven were of genotype $E_{1}^{u} E_{1}^{a}$, three were $E_{1}^{u} E_{1}^{s}$, and four $E_{1}^{a} E_{1}^{s}$. Nine members of the family were considered to be at risk for the administration of suxamethonium. The appropriate action to safeguard other members of the family following a case of apnoea is outlined. By routine preoperative blood examination, 92 of 100 cases of suxamethonium apnoea resulting from a genetic abnormality of plasma cholinesterase can be anticipated.

Suxamethonium (succinyldicholine, Scoline), a depolarising neuromuscular blocking agent, is widely used as a short acting muscular relaxant. It is hydrolysed by the enzyme acylcholine acylhydrolase with the code number E.C.3.1.1.8, commonly known as plasma cholinesterase (ChE). The average adult dose of $1 \mathrm{mg} / \mathrm{kg}$ body weight produces respiratory paralysis by peripheral action of two to four minutes' duration. A period of apnoea lasting more than 10 minutes is considered abnormal.

Before incriminating a genetic abnormality of $\mathrm{ChE}$, apnoea of central origin, or resulting from the anaesthetic agent or technique, or certain antibiotics, ${ }^{12}$ or abdominal surgery itself, ${ }^{3}$ have to be excluded. Moreover various diseases and drugs can affect ChE. ${ }^{4}$

The following case illustrates the latent hazard which every anaesthetist fears when, following suxamethonium used routinely and in a single dose in a fit person during the course of a normal operating list, apnoea occurred as a result of a genetic abnormality of the ChE.

\section{Case report}

A housewife aged 50 , weighing $53 \mathrm{~kg}$, was admitted to hospital for $\mathrm{D}$ and $\mathrm{C}$, curettage and cauterisation of the cervix. Premedication was an intramuscular injection of pethidine $50 \mathrm{mg}$ and atropine $0.6 \mathrm{mg}$. Received for publication 10 March 1981
Sleep was induced with $100 \mathrm{mg}$ methohexitone sodium intravenously followed by intravenous injection of $100 \mathrm{mg}$ suxamethonium chloride. After intubation anaesthesia was maintained with nitrous oxide-oxygen $(5: 3 \mathrm{l} / \mathrm{m})$ and 0.5 to $1.0 \%$ halothane. Apnoea persisted for 90 minutes despite ventilation with 5 to $6 \mathrm{l} / \mathrm{m}$ oxygen and full respiration did not return for a further 30 minutes. A peripheral nerve stimulator was not available. Blood gas analysis carried out half an hour after apnoea showed a $\mathrm{pH}$ of $7 \cdot 05, \mathrm{PCO}_{2} 12 \cdot 5 \mathrm{kPa}(94 \mathrm{mmHg}), \mathrm{Po}_{2} 28 \cdot 1 \mathrm{kPa}$ (211 $\mathrm{mmHg}$ ), plasma bicarbonate $22.9 \mathrm{mmol} / \mathrm{l}$, base excess $-10 \mathrm{mmol} / \mathrm{l}$. One hour later when recovery was taking place the values were $\mathrm{pH} 7 \cdot 32$, $\mathrm{PCO}_{2} 6.0 \mathrm{kPa}$ (44 mmHg), $\mathrm{Po}_{2} 20.0 \mathrm{kPa}(150 \mathrm{mmHg}$ ), plasma bicarbonate $19 \mathrm{mmol} / \mathrm{l}$, base excess -6 $\mathrm{mmol} / \mathrm{l}$. The plasma cholinesterase, as repeated after discharge, was 22 units, the dibucaine number 18, and fluoride number 17.

As a result of the suxamethonium apnoea and the associated abnormal $\mathrm{ChE}$ the author decided to examine the blood of other members of the family. Nineteen out of a possible 21 (I 2 was not alive) were investigated. IV $\cdot 2$ (aged 11 months) and II 6 were not examined.

\section{Methods}

ChE activity ( $100 \times$ change in $\mathrm{pH}$ in one hour) was estimated with benzoylcholine as substrate using the 
ultraviolet spectrophotometer. ${ }^{5}$ The differential inhibition by dibucaine hydrochloride ${ }^{6}$ and sodium fluoride $^{7}$ enabled the dibucaine number (DN) and fluoride number (FN) to be determined.

\section{Results}

The figure sets out the relationship of the members of the family to the proband, together with their genotypes. Table 1 shows the cholinesterase activity, details of the inhibition studies, genotypes, and suxamethonium sensitivity for each of the members tested. It will be seen that of the 19 subjects examined nine were considered to be sensitive to suxamethonium.

\section{Discussion}

Although the blood gas analysis showed that the patient was inadequately ventilated, the primary cause of the prolonged apnoea was considered to be a genetic abnormality of the cholinesterase.
There are four allelic genes of importance to the anaesthetist which control $\mathrm{ChE}$ activity and which function at the same locus, designated $E_{1}$ using the nomenclature of Motulsky. ${ }^{8}$ These are the usual $E_{1}^{u}$, the dibucaine resistant or atypical $E_{1}^{a}$, 9 the fluoride resistant $E_{1}^{f},{ }^{70-12}$ and the silent gene $E_{1}^{s}{ }^{13}$ They give rise to ten genotypes whose characteristics are given in table 2 , based on the work of Whittaker on a cross-section of the British population. ${ }^{4}$ It will be seen that six of the genotypes are associated with a distinctly increased sensitivity to suxamethonium.

The estimation of the DN and FN enables recognition of groups containing the genes $E_{1}^{u}$, $E_{1}^{\text {, }}$, and $E_{1}^{f}$, but not $E_{1}^{s}$, as heterozygotes with the silent gene have the same DN and FN as the homozygous phenotype. Its presence may be suspected when the ChE activity is below that which would be expected for the corresponding homozygote, but confirmation requires family studies. Thus, in table $1, \mathrm{II} \cdot 3$ and III 4 are of genotype $E_{1}^{u} E_{1}^{s}$ not $E_{1}^{u} E_{1}^{u}$, and similarly II $\cdot 1$, II $\cdot 5$, II $\cdot 7$,

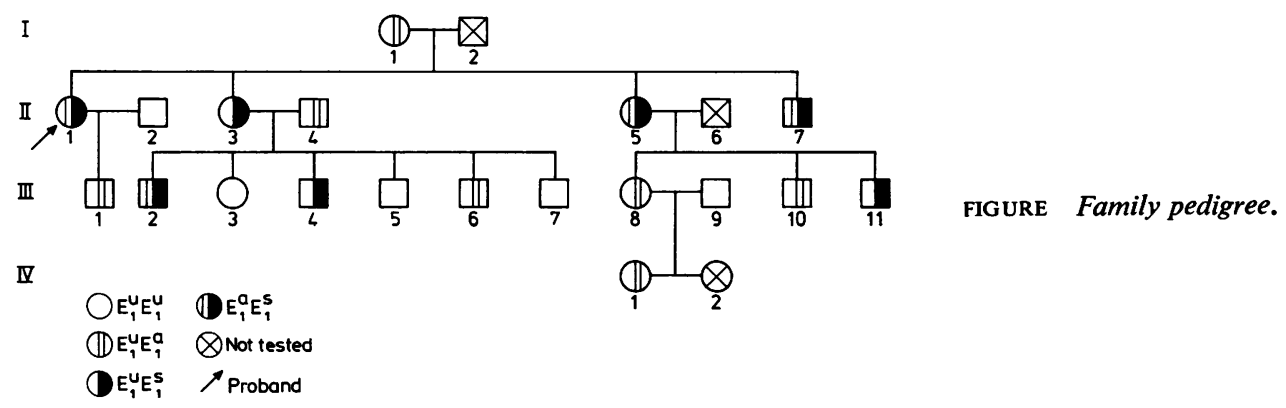

TABLE 1 Plasma cholinesterase activity, dibucaine and fluoride number, genotype, and suxamethonium activity for each member examined as shown in the figure

\begin{tabular}{|c|c|c|c|c|c|c|c|}
\hline Subject & Sex & Age & $\begin{array}{l}\text { Plasma } \\
\text { cholinesterase }\end{array}$ & $D N$ & $F N$ & Genotype & $\begin{array}{l}\text { Suxamethonium } \\
\text { sensitivity }\end{array}$ \\
\hline 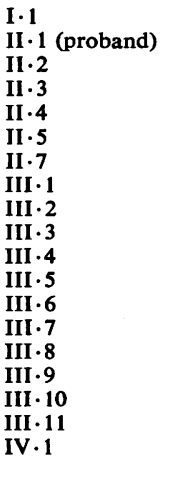 & $\begin{array}{l}\mathbf{F} \\
\mathbf{F} \\
\mathbf{M} \\
\mathbf{F} \\
\mathbf{M} \\
\mathbf{F} \\
\mathbf{M} \\
\mathbf{M} \\
\mathbf{M} \\
\mathbf{F} \\
\mathbf{M} \\
\mathbf{M} \\
\mathbf{M} \\
\mathbf{M} \\
\mathbf{F} \\
\mathbf{M} \\
\mathbf{M} \\
\mathbf{M} \\
\mathbf{F}\end{array}$ & $\begin{array}{r}74 \\
50 \\
53 \\
46 \\
49 \\
47 \\
43 \\
25 \\
21 \\
23 \\
19 \\
18 \\
15 \\
14 \\
28 \\
30 \\
27 \\
11 \\
5\end{array}$ & $\begin{array}{r}101 \\
22 \\
99 \\
57 \\
75 \\
21 \\
34 \\
22 \\
26 \\
89 \\
46 \\
81 \\
80 \\
132 \\
48 \\
129 \\
104 \\
81 \\
101\end{array}$ & $\begin{array}{l}65 \\
18 \\
84 \\
81 \\
61 \\
24 \\
22 \\
63 \\
22 \\
82 \\
80 \\
78 \\
66 \\
83 \\
63 \\
82 \\
67 \\
82 \\
63\end{array}$ & $\begin{array}{l}50 \\
17 \\
60 \\
60 \\
48 \\
21 \\
19 \\
45 \\
26 \\
62 \\
57 \\
58 \\
49 \\
61 \\
48 \\
58 \\
48 \\
60 \\
45\end{array}$ & 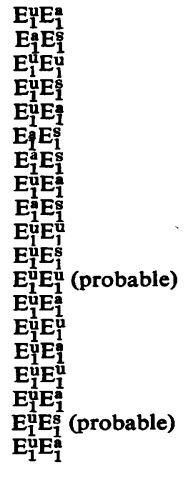 & $\begin{array}{l}\text { No } \\
\text { Yes } \\
\text { No } \\
\text { Yes } \\
\text { Probably not } \\
\text { Yes } \\
\text { Yes } \\
\text { Yes } \\
\text { Yes } \\
\text { No } \\
\text { Yes } \\
\text { Probably not } \\
\text { Probably not } \\
\text { No } \\
\text { Yes } \\
\text { No } \\
\text { No } \\
\text { Probably not } \\
\text { Yes, especially } \\
\text { if pregnant }\end{array}$ \\
\hline
\end{tabular}


TABLE 2 Distribution, suxamethonium sensitivity, and biochemical characteristics of plasma cholinesterase variants in a British population.

\begin{tabular}{|c|c|c|c|c|c|c|c|c|}
\hline \multirow[t]{2}{*}{ Genotype } & \multirow[t]{2}{*}{ Group } & \multirow{2}{*}{$\begin{array}{l}\text { Relative } \\
\text { mean } \\
\text { enzyme } \\
\text { activity }\end{array}$} & \multicolumn{2}{|c|}{ Dibucaine No } & \multicolumn{2}{|c|}{ Fluoride No } & \multirow[t]{2}{*}{ Frequency } & \multirow{2}{*}{$\begin{array}{l}\text { Suxamethonium } \\
\text { sensitivity }\end{array}$} \\
\hline & & & Mean & Range & Mean & Range & & \\
\hline $\begin{array}{l}\mathbf{E}_{1}^{u} E_{1}^{u} \\
E_{1}^{u} E_{1}^{s} \\
E_{1}^{u} E_{1}^{p} \\
E_{1}^{u} E_{1}^{\text {a }} \\
E_{1}^{a} E_{1}^{f} \\
E_{1}^{f} E_{1}^{f}\end{array}$ & $\begin{array}{l}\text { Usual ' } U \text { ' } \\
\text { Fluoride resistant ' } U_{1} \text { ' } \\
\text { Intermediate 'I' } \\
\text { Fluoride resistant ' } I_{1} \text { ' } \\
\text { Homozygous fluoride } \\
\text { resistant }\end{array}$ & $\begin{array}{r}100 \\
70 \\
86 \\
77 \\
59 \\
74\end{array}$ & $\begin{array}{l}80 \\
80 \\
74 \\
62 \\
53 \\
67\end{array}$ & $\begin{array}{l}77-83 \\
77-83 \\
70-83 \\
48-69 \\
45-59 \\
64-69\end{array}$ & $\begin{array}{l}61 \\
61 \\
52 \\
50 \\
33 \\
36\end{array}$ & $\begin{array}{l}56-68 \\
56-68 \\
46-54 \\
44-54 \\
28-39 \\
34-43\end{array}$ & $\begin{array}{l}96 \% \\
1 \text { in } 190 \\
1 \text { in } 200 \\
1 \text { in } 25 \\
1 \text { in } 20000 \\
1 \text { in } 154000\end{array}$ & $\begin{array}{l}\text { ? } 1 \text { in } 2500 \text { moderately sensitive } \\
\text { ? } 1 \text { in } 1000 \text { moderately sensitive } \\
\text { ? } 1 \text { in } 100 \text { moderately sensitive } \\
\text { ? } 1 \text { in } 500 \text { moderately sensitive } \\
\text { All moderately sensitive } \\
\text { All moderately sensitive }\end{array}$ \\
\hline $\begin{array}{l}E_{1}^{p} E_{1}^{s} \\
E_{1}^{\mathrm{a}} E_{1}^{\mathrm{a}}\end{array}$ & $\begin{array}{l}\text { Dibucaine resistant } \\
\text { or atypical 'A' }\end{array}$ & $\begin{array}{l}37 \\
43\end{array}$ & $\begin{array}{l}67 \\
21\end{array}$ & $\begin{array}{r}64-69 \\
8-28\end{array}$ & $\begin{array}{l}36 \\
19\end{array}$ & $\begin{array}{l}34-43 \\
10-28\end{array}$ & $\begin{array}{l}1 \text { in } 150000 \\
1 \text { in } 2000\end{array}$ & $\begin{array}{l}\text { All moderately sensitive } \\
\text { All very sensitive }\end{array}$ \\
\hline $\begin{array}{l}\mathbf{E}_{1}^{\mathbf{a}} \mathbf{E}_{1}^{\mathbf{s}} \\
\mathbf{E}_{1}^{\mathbf{s}} \mathbf{E}_{1}^{\mathbf{s}}\end{array}$ & $\begin{array}{l}\text { Homozygous silent } \\
\text { variant }\end{array}$ & $\begin{array}{l}22 \\
\text { Enzyme }\end{array}$ & $\begin{array}{l}21 \\
\text { ctivity ni }\end{array}$ & $\begin{array}{c}8-28 \\
\text { r too lov }\end{array}$ & $\begin{array}{l}19 \\
\text { measure }\end{array}$ & $10-28$ & $\begin{array}{l}1 \text { in } 29000 \\
1 \text { in } 100000\end{array}$ & $\begin{array}{l}\text { All very sensitive } \\
\text { All very sensitive }\end{array}$ \\
\hline
\end{tabular}

and III $\cdot 2$ are not $E_{1}^{a} E_{1}^{a}$ but $E_{1}^{a} E_{1}^{s}$. These latter subjects demonstrate the general rule that those with a low DN have a low ChE. The converse, however, is not necessarily true as is seen in the case of $\mathrm{II} \cdot 3$ and III $\cdot 4$.

Not all genotypes $\mathrm{E}_{1}^{\mathrm{u}} \mathrm{E}_{1}^{\mathrm{s}}$ have a low $\mathrm{ChE}$, as pointed out by Liddell et $a l,{ }^{13}$ and as is seen in III $\cdot 11$. It is not unusual in this type of heterozygosity for one gene to do the work of almost two.

Those subjects designated 'probably not' in table 1 are males. Had they been females they would have been issued with cholinesterase warning cards, as there can be at least a $25 \%$ drop in the ChE during pregnancy and early postpartum period. ${ }^{14}$

Seven members of the family are of genotype $E_{1}^{u} E_{1}^{a}$. Subjects with this phenotype are issued with a warning card if they are females and premenopausal, irrespective of their ChE level, or if they are males with a ChE of less than $50 \%$ of the usual group. ${ }^{4}$ This practice differs from that in Denmark where all subjects with an abnormal genotype are issued with a warning card..$^{15}$

IV $\cdot 1$, aged 5 , is considered at risk not only because she is female and heterozygous, but because at this age the $\mathrm{ChE}$ is about $35 \%$ above the adult level ${ }^{16} 17$ so that her present adequate level (101) will decrease over the next 7 to 8 years.

In the case of IV 2 , a female child aged 11 months, blood examination is being postponed until the age of 5 . In the meantime, since it is known that at birth the ChE is low, ${ }^{18-21}$ the parents and the general practitioner were advised that suxamethonium should be avoided, as suxamethonium apnoea in infancy, although rare, has been recorded. ${ }^{22}$ This child is genetically at risk because of the possibility of having an abnormal genotype $\mathrm{E}_{1}^{\mathrm{u}} \mathrm{E}_{1}^{\mathrm{a}}$, as the parents (III $\cdot 8$ and III $\cdot 9$ ) are $E_{1}^{u} E_{1}^{a}$ and $E_{1}^{u} E_{1}^{u}$, and is also liable to have a low ChE because one of the parents (III.8) has a ChE of only 48 and this reduced $\mathrm{ChE}$ activity can be transmitted inde- 을 pendently.

Five subjects are of normal genotype $\mathrm{E}_{1} \mathrm{E}_{1}^{\mathrm{u}}$ with adequate $\mathrm{ChE}$ and are therefore considered not to be sensitive to suxamethonium. It is important to bear in mind that some subjects show sensitivity to $₹$ suxamethonium even though they fall in the normal $\overrightarrow{0}$ group and have normal enzyme activity. ${ }^{415}$ This $\stackrel{\infty}{N}$ anomaly has so far not been satisfactorily explained.

Berry and Whittaker ${ }^{23}$ showed that $13 \%$ of relatives of those sensitive to suxamethonium were themselves sensitive. In this study, the figure is nearer $50 \%$ because of the preponderance of the $\frac{2}{D}$ silent gene (seven out of 19 members). For the same $ᄋ$ reason the high incidence of apnoea because of the $\overrightarrow{\overrightarrow{0}}$ silent gene (six out of nine cases) contrasts with the low incidence of $1 \%$ in Whittaker's review of over 1000 cases of suxamethonium sensitive subjects. ${ }^{4}$ The preponderance of the silent gene in this family study is the result of $I \cdot 2$, the father of the proband and no longer alive, being almost certainly of $\frac{5}{3}$ genotype $\mathrm{E}_{1}^{\mathrm{s}} \mathrm{E}_{1}^{\mathrm{s}}$. This can be deduced in accordance with simple Mendelian inheritance because the offspring of I $\cdot 1$ and $\mathrm{I} \cdot 2$ (II $\cdot 1, \mathrm{II} \cdot 3, \mathrm{II} \cdot 5$, and II $\cdot 7)$ all possess the silent gene and $I \cdot 1$ does not.

As a result of this family study, each subject at $D$ risk was issued with a warning card of suxamethonium sensitivity by the Cholinesterase $\mathrm{Re}-\stackrel{N}{N}$ search Unit. In addition they also wear a bracelet or necklace with a disc upon which is inscribed in 0 contrast colour "No Scoline". Their general $\omega$ practitioners were also informed.

The occurrence of suxamethonium apnoea in $\bullet$ clinical practice is estimated at 1 in 2400 cases. ${ }^{24} \Phi$ Since the incidence of apnoea as a result of a genetic $\stackrel{?}{?}$ abnormality of the cholinesterase is 1 in $1500,{ }^{25}$ and that resulting from all the phenotypes containing $\frac{O}{\mathbb{D}}$ the silent gene is as low as 1 in 20000 (deduced from table 2), it can be seen that, out of 100 subjects $\stackrel{D}{\square}$ 
sensitive to suxamethonium as a result of a genetic abnormality, 92 can be determined and anticipated by the routine preoperative estimation of the ChE level together with the DN and FN. A plea, therefore, is made that once a case of suxamethonium apnoea is encountered in hospital practice, there should be an organised machinery for ensuring that all relatives are screened at a specialised centre which is capable of dealing with the difficulties of phenotyping and of carrying out family studies.

The author would like to thank Dr R N Atherstone, Consultant Anaesthetist, King George and London Chest Hospital, for his encouragement and permission to study his patient. My thanks are also due to Dr Mary Whittaker of the Cholinesterase Research Unit and Reference Centre of the Department of Chemistry, University of Exeter, for carrying out the cholinesterase estimations and determining the genotypes. Lastly, I would like to express my appreciation to the many members of the family who travelled great distances to accommodate the author.

Table 2 is reproduced by kind permission of Dr Mary Whittaker and the Editor of Anaesthesia. ${ }^{4}$

\section{References}

1 Pittinger CB, Eryasa Y, Adamson R. Antibiotic-induced paralysis. Anesth Analg (Cleve) 1970;49:487-501.

2 Pittinger C, Adamson R. Antibiotic blockade at neuromuscular function. Ann Rev Pharmacol 1972;12:169-84.

3 Anscombe AR. Pulmonary complications of abdominal surgery. London: Lloyd-Luke, 1957:55.

4 Whittaker M. Plasma cholinesterase variants and the anaesthetist. Anaesthesia 1980;35:174-97.

5 Kalow W, Lindsay HA. A comparison of optical and manumetric methods for the assay of human serum cholinesterase. Can J Biochem 1955;33:568-74.

6 Kalow W, Genest K. A method for the detection of atypical forms of human serum cholinesterase: determination of dibucaine numbers. Can J Biochem 1957;35:33946.

7 Harris H, Whittaker M. Differential inhibition of human serum cholinesterase with fluoride: recognition of two new phenotypes. Nature $1961 ; 191: 496-8$.
8 Motulsky AG. Pharmacogenetics. In: Steinberg AG, Bearn AG, eds. Progress in medical genetics. New York, London: Grune and Stratton, 1964:49-74.

- Kalow W, Staron N. On distribution and inheritance of atypical forms of human serum cholinesterase, as indicated by dibucaine numbers. Can J Biochem 1957;35: 1305-20.

10 Liddell J, Lehmann H, Davies D. Harris and Whittaker's pseudocholinesterase variant with increased resistance to fluoride: a study of four families and the identification of the homozygote. Acta Genet Stat Med 1963;13:95-108.

11 Whittaker M. The pseudocholinesterase variants: esterase levels and increased resistance to fluoride. Acta Genet Stat Med 1964;14:281-5.

12 Whittaker M. The pseudocholinesterase variants. A study of fourteen families selected via the fluoride resistant phenotype. Acta Genet Stat Med 1967;17:1-12.

15 Liddell J, Lehmann H, Silk E. A 'silent' pseudocholinesterase gene. Nature 1962;193:561-2.

14 Robertson GS. Serum cholinesterase deficiency. II. Pregnancy. Br J Anaesth 1966;38:361-9.

15 Viby-Mogensen J, Hanel HK. Prolonged apnoea after suxamethonium: an analysis of the first 225 cases reported to the Danish Cholinesterase Research Unit. Acta Anaesthesiol Scand 1978;22:371-80.

16 Hutchinson AO, Widdowson EM. Cholinesterase activities in the serum of healthy British children. Nature 1952;169:284-5.

17 Dabew D. Cholinesterase- und Transaminasen- Aktivität im Serum von Kindern ( 3 bis 6 Jahre alt). $Z$ Klin Chemie Klin Biochemie 1970;8:12-6.

18 Bleisch VR, Shwachman H. Serum cholinesterase values in childhood in health and disease. Pediatrics 1954;13: 426-38.

19 Abderhalden R. Clinical enzymology. Princeton, NJ : Van Nostrand, 1960:41.

20 Lehmann H, Cook J, Ryan E. Pseudocholinesterase in early infancy. Proc $R$ Soc Med 1957;50:147-9.

21 Brody S. Plasma cholinesterase activity in the newborn infant. Acta Obstet Gynaecol Scand 1960;39:1-18.

22 Kaufman L, Lehmann H, Silk E. Suxamethonium apnoea in an infant. Expression of familial pseudocholinesterase deficiency in three generations. Br Med J 1960;i:166-7.

${ }^{23}$ Berry $M$, Whittaker $M$. Incidence of suxamethonium apnoea in patients undergoing ECT. Br J Anaesth 1975; 47:1195-7.

24 Churchill-Davidson HC. The changing pattern of neuromuscular block. Can Anaesth Soc J 1961;8:91-8.

25 Kalow W. Pharmacogenetics and anesthesia. Anesthesiology $1964 ; 25: 337-87$.

Requests for reprints to Dr Alan A Morgan, 37 Holcombe Road, Ilford, Essex IG1 4XF. 